\title{
High-fat diets affect the expression of nuclear retinoic acid receptor in rat liver
}

\author{
S. Bonilla, A. Redonnet, C. Noël-Suberville, V. Pallet, H. Garcin and P. Higueret* \\ Laboratoire de Nutrition-ISTAB, Université Bordeaux I, Avenue des Facultés, 33405 Talence-Cedex, France
}

(Received 16 April 1999 - Revised 28 September 1999 - Accepted 26 October 1999)

\begin{abstract}
The purpose of this study was to differentiate between the effects of the amount and the type of dietary lipids on the expression of the retinoic acid receptor (RAR), but also the peroxisome proliferator-activated receptor (PPAR) and the receptor of the 9-cis retinoic acid (retinoid X receptor (RXR)) in rat liver. Six groups of eight rats (5-weeks old) were fed during 4 weeks on the following diets: control $50 \mathrm{~g}$ vegetable oil $/ \mathrm{kg}$, high-fat diet $250 \mathrm{~g}$ vegetable oil $/ \mathrm{kg}$. These oils were either coconut oil (rich in saturated fatty acids) or olive oil (rich in monounsaturated fatty acids) or safflower oil (rich in polyunsaturated fatty acids, mainly as $n-6$ ). The three high-fat diets induced a significant decrease of the maximal binding capacity of RAR and of the abundance of $\operatorname{RAR} \beta$ mRNA. Simultaneously, an increased expression of PPAR $\alpha$ mRNA was observed while no significant difference on abundance of $\operatorname{RXR} \alpha$ mRNA was observed. The mechanisms involved are probably multiple, but one hypothesis is that a modification of the equilibrium between the nuclear receptors, resulting from an increased expression of PPAR, induces a decreased expression of RAR in rat liver.
\end{abstract}

Rat liver: High-fat diet: Retinoic acid receptor expression

Biologically active derivatives of vitamin A (essentially retinoic acids) are indispensable for many essential physiological processes in a number of tissues (Mangelsdorf et al. 1994) and a recent study shows a role for vitamin A derivatives in energy balance (Villaroya, 1998). Retinoid signalling is mediated by two classes of receptors, retinoic acid receptors $(\operatorname{RAR} \alpha,-\beta$ and $-\gamma)$ and retinoid $\mathrm{X}$ receptors ( $\operatorname{RXR} \alpha,-\beta$ and $-\gamma$ ). These receptors belong to the steroid/ thyroid nuclear receptor family and are DNA-binding proteins, which upon activation by specific retinoid ligands, induce gene transcription by interacting with distinct promoter sequences in the target genes (Mangelsdorf et al. 1994). The expression of RAR is modulated by nutritional and hormonal status. Thus, RAR is under-expressed in the liver of vitamin A-deficient rats (Haq et al. 1991; Verma et al. 1992; Audouin-Chevallier et al. 1993), hypothyroid rats (Pallet et al. 1994; Coustaut et al. 1996) or dexamethasone-treated rats (Pallet et al. 1996) and is over-expressed in the liver of vitamin A-overloaded rats (Audouin-Chevallier et al. 1993).

Recently, we showed that a hyperlipidic diet rich in saturated fatty acids (SFA), with (Noël-Suberville et al. 1998) or without (Bonilla et al. 1998) added cholesterol, induced a decreased expression of $\operatorname{RAR} \beta$. In the discussion of these papers, we claimed that these results could be due to numerous mechanisms and that the relative role of each characteristic of the used diet (energy intake and nature of the dietary lipid) needed to be elucidated. Thus, the aims of this present study were: (1) to determine the role of the amount of dietary lipid $v$. the role of the type of fatty acids in the lipids by comparing the effects of diets containing either 50 or $250 \mathrm{~g}$ coconut oil (rich in SFA) or olive oil (rich in monounsaturated fatty acids (MUFA)) or safflower oil (rich in polyunsaturated fatty acids (PUFA)); (2) to propose a mechanistic explanation of the observed result focused on the involvement of peroxisome proliferator-activated receptors (PPAR). Indeed, PPAR are members of the nuclear hormone receptor superfamily activated by a broad class of structurally diverse xenobiotic chemicals called peroxisome proliferators, as well as by certain fatty acids (Isseman \& Green, 1990; Green \& Wahli, 1994; Kliewer et al. 1997).

Positive gene regulation by PPAR has been shown to involve the heterodimerization of these receptors with RXR, indicating that the retinoid and peroxisome proliferator signalling pathways converge through the direct interaction of their respective nuclear receptors (Gearing et al. 1993; Keller et al. 1993; Miyata et al. 1994).

In this present study, the expression of RAR was evaluated by an isotopic displacement analysis and by quantitation of $\operatorname{RAR} \beta$ while the expression of $\operatorname{RXR} \alpha$ and $\operatorname{PPAR} \alpha$

\footnotetext{
Abbreviations: CD, control diet; HFD, high-fat diet; MUFA, monounsaturated fatty acid; PPAR, peroxisome proliferator-activated receptor; RAR, retinoic acid receptor; RXR, retinoid $X$ receptor; SFA, saturated fatty acid.

* Corresponding author: Professor P. Higueret, fax +33 5568427 76, email p.higueret@istab.u-bordeaux.fr
} 
was evaluated by quantifying the mRNA of $\operatorname{RXR} \alpha$ and $\operatorname{PPAR} \alpha$ (all the quantified isoforms are well expressed in rat liver). Also, we quantified the liver acyl-CoA oxidase (EC 1.2.1.50) mRNA because the corresponding enzymic activity is induced by drugs known to cause peroxisomal proliferation (Lazarow \& de Duve, 1976; Sterchele et al. 1996; Latruffe \& Vamecq, 1997).

\section{Methods \\ Experimental design}

Official French regulations for the care and use of laboratory animals were followed. Male Wistar rats weighing 100$120 \mathrm{~g}$ were obtained from IFFA-CREDO (L'Arbresle, France), and were housed two to a cage in an air-conditioned room of mean temperature $21^{\circ}$ and with a photoperiod that followed the seasonal pattern, varying from $10-12 \mathrm{~h}$ light/d during the experiment. The animals had free access to drinking water and diet and were weighed twice per week. The diets were semisynthetic diets consisting of a powder containing all the dietary components, except lipids, mixed with $50 \mathrm{~g}$ (control diet (CD)) or $250 \mathrm{~g}$ (high-fat diet (HFD)) vegetable oil $/ \mathrm{kg}$. The composition of the diet was calculated so that the proportion of protein in the diets was constant $(180 \mathrm{~g} / \mathrm{kg})$ whatever the proportion of lipids (Table 1). The oils used were coconut oil (containing approximately $760 \mathrm{~g} / \mathrm{kg}$ SFA, mainly as lauric acid and myristic acid (12:0 and 14:0 respectively)), olive oil (containing approximately $760 \mathrm{~g} / \mathrm{kg}$ MUFA as oleic acid $(18: 1))$ and safflower oil (containing approximately $770 \mathrm{~g} / \mathrm{kg}$ PUFA, mainly as linoleic acid $(18: 2 n-6))$. The fatty acid composition of the various diets is given in Table 2. To minimize oxidation, oils were stored in the dark at $4^{\circ}$, under $\mathrm{N}_{2}$ and in separate containers; diets were freshly mixed three times per week. The HFD provided $20.85 \mathrm{MJ} / \mathrm{kg}$ diet while the $\mathrm{CD}$ provided only $16.65 \mathrm{MJ} / \mathrm{kg}$ diet. Rats were killed by decapitation (between 09.00 and 10.00 hours) $28 \mathrm{~d}$ after the start of dietary treatment. Blood was collected and the liver was rapidly

Table 1. Composition of the diets $(\mathrm{g} / \mathrm{kg})^{*}$

\begin{tabular}{|c|c|c|}
\hline Component & $\begin{array}{c}\text { CD } \\
(50 \mathrm{~g} \text { lipid/kg) }\end{array}$ & $\begin{array}{c}\text { HFD } \\
\text { (250 g lipid } / \mathrm{kg})\end{array}$ \\
\hline Casein & 180 & 180 \\
\hline Vegetable oil & 50 & 250 \\
\hline Maize starch & 420 & 325 \\
\hline Sucrose & 275 & 170 \\
\hline Cellulose & 20 & 20 \\
\hline Salt mixture $\dagger$ & 45 & 45 \\
\hline Vitamin mixture $\ddagger$ & 10 & 10 \\
\hline
\end{tabular}

$\mathrm{CD}$, control diet; HFD, high-fat diet.

* The alipidic powder was prepared according to Atelier de Préparation d'Aliments Expérimentaux (INRA, 78350 Jouy en Josas, France).

† Salt mixture no. 102 from INRA (Pottier de Courcy et al. 1989) consisted of the following (g/kg): Ca 158, K 104, Na 27, Mg 21, Zn 1.82, Fe 1.72, Mn 1.49, Cu 0.244, Cr 0.044, Co 0.011, P 109, Cl 40, S 15, F 0.33, I 0.033, Se 0.009, Mo 0.011 , sucrose, to make a final weight of $1 \mathrm{~kg}$.

¥Vitamin diet mixture no. 102 from INRA (Pottier de Courcy et al. 1989) consisted of the following $(\mathrm{g} / \mathrm{kg})$ : retinyl palmitate 0.15 , cholecalcifero 0.00625 , DL- $\alpha$-tocopherol acetate 5 , menadione 0.1 , thiamin $\mathrm{HCl} 1$, riboflavin 1, nicotinic acid 4.5, D-calcium panthotenate 3 , pyridoxine $\mathrm{HCl} 1$, inosotol 5 , D-biotin 0.02 , folic acid 0.2 , cyanocobalamin 0.00135 , ascorbic acid 10 $p$-amino benzoic acid 5 , choline 75 , sucrose, to make a final weight of $1 \mathrm{~kg}$.
Table 2. Fatty acid composition of the diets ( $\mathrm{g} / 100 \mathrm{~g}$ total fatty acids)*

\begin{tabular}{lccc}
\hline & \multicolumn{3}{c}{ Diet } \\
\cline { 2 - 4 } Fatty acid & CO & OO & SO \\
\hline $8: 0$ & $7 \cdot 2$ & $-\dagger$ & - \\
$10: 0$ & $5 \cdot 9$ & - & - \\
$12: 0$ & $47 \cdot 7$ & - & - \\
$14: 0$ & $17 \cdot 7$ & - & $0 \cdot 1$ \\
$16: 0$ & $9 \cdot 1$ & $10 \cdot 2$ & $7 \cdot 1$ \\
$18: 0$ & $2 \cdot 8$ & $3 \cdot 2$ & $2 \cdot 8$ \\
$18: 1 n-9$ & $7 \cdot 3$ & $76 \cdot 4$ & 10 \\
$18: 2 n-6$ & $1 \cdot 9$ & $5 \cdot 7$ & $77 \cdot 7$ \\
$18: 3 n-3$ & - & $0 \cdot 8$ & 0.1 \\
$20: 0$ & $0 \cdot 1$ & $0 \cdot 4$ & $0 \cdot 3$ \\
Other & $0 \cdot 3$ & $3 \cdot 3$ & $1 \cdot 9$
\end{tabular}

$\mathrm{CO}$, coconut-oil diet; OO, olive-oil diet; SO, safflower-oil diet.

*Determined after chloroform-methanol $(2: 1, \mathrm{v} / \mathrm{v})$ extraction according to Folch et al. (1957) and methylation by boron fluoride $(140 \mathrm{~g} / \mathrm{l}$ methanol) at $100^{\circ}$ for $10 \mathrm{~min}$; methylated extracts were analysed by GLC. $\dagger(-)$, not detected.

$\ddagger$ Includes fatty acids detected at $<0.1 \mathrm{~g} / 100 \mathrm{~g}$ of total fatty acids and fatty acids not identified.

excised and washed twice in cold saline $(9 \mathrm{~g} \mathrm{NaCl} / \mathrm{l})$ solution. Portions of the liver were immediately frozen in liquid $\mathrm{N}_{2}$ and stored at $-80^{\circ}$ for subsequent analysis.

\section{Hormone binding}

Binding properties of RAR in rat liver were determined by in vitro studies. All tissue fractionations were carried out at $4^{\circ}$. Nuclei were prepared according to the method of DeGroot \& Torresani (1975) and the study of RAR binding was performed according to Audouin-Chevallier et al. (1993), using a synthetic analogue of retinoic acid, CD367. Scatchard curves (Scatchard, 1949) were drawn using linear regression analysis of the data. The slope of the straight line gave the dissociation constant $\left(K_{\mathrm{d}}\right)$ and the intercept of the slope with the abscissa represented the maximum binding capacity $\left(\mathrm{C}_{\max }\right)$, i.e. the concentration of binding sites.

\section{Quantification of $m R N A$}

mRNA were quantified using a semi-quantitative method, by reverse transcription and amplification by the polymerase chain reaction. The values of mRNA were obtained by comparison with the level of an internal standard, $\beta$-actin, which was simultaneously reverse-transcribed and amplified in the same test tube. Indeed, fatty acids in vivo (Clarke \& Jump, 1993) as well as in vitro (Poirier et al. 1997) do not affect the expression of $\beta$-actin. The extraction of RNA, cDNA preparation, polymerase chain reaction analysis and quantitative determination of polymerase chain reaction products were performed as previously described (Coustaut et al. 1996). The choice of the quantified mRNA isoforms was justified by the following considerations: $\operatorname{RAR} \beta$ is subject to nutritional regulation in rat liver (Kato et al. 1992), $\operatorname{RXR} \alpha$ is widely distributed and abundant in rat liver (Mangelsdorf et al. 1992), PPAR $\alpha$ mRNA has a high level in adult rat liver (Braissant et al. 1996).

The positions and sequences of the different oligonucleotide primers used are available upon request. Primers were 


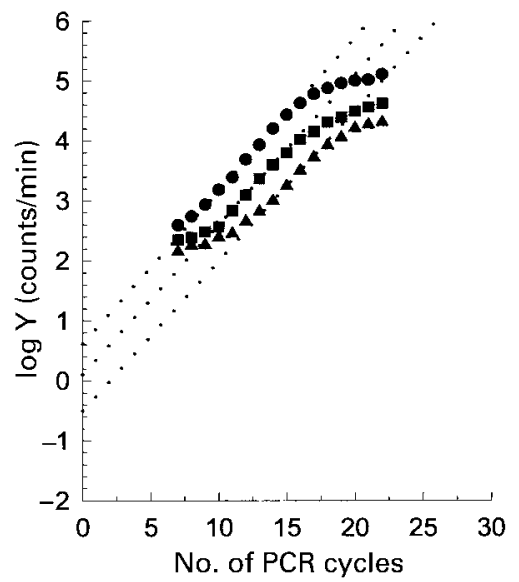

Fig. 1. Relative quantification of peroxisome proliferator-activated receptor (PPAR) $\alpha$ and acyl-CoA oxidase transcripts by reverse transcription and amplification and polymerase chain reaction (RT$\mathrm{PCR}$ ) in rat liver. The products of RT-PCR were resolved on $10 \%$ acrylamide gel electrophoresis and the amount of $\left[\alpha^{32} \mathrm{P}\right] \mathrm{dCTP}$ incorporated was counted, followed by a semilogarithmic representation of the relative amplification (Y). The PCR efficiency was $82 \%$.

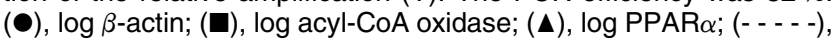
regression.

purchased from GENSET (Paris, France). Fig. 1 shows, for example, the semilogarithmic representation of the relative amplification products of $\beta$-actin, PPAR and acyl-CoA oxidase genes measured by counting the amount of ${ }^{32} \mathrm{P}$ incorporated.

\section{Statistical procedure}

Experimental values are expressed as means with standard errors. The statistical signification of oil-level and oil-type effects and of their interaction was calculated by a two-way ANOVA. The differences between values obtained in rats fed $50 \mathrm{~g}$ (CD) or $250 \mathrm{~g}$ (HFD) oil $/ \mathrm{kg}$ of the same oil were then analysed according to the Tukey's multiple post hoc test.

\section{Results}

The results of the two-way ANOVA (Table 3) showed that the type of the dietary oil (coconut, olive or safflower oil) did not affect any of the variables studied. In contrast, the variables were affected when the level of the oil in the diet was increased from 50 to $250 \mathrm{~g} / \mathrm{kg}$. An interaction between the two factors (oil type and oil level) was not observed.

\section{Status of rats}

According to the two-way ANOVA, the oil level induced an effect upon food and energy intake. Food intake was less, and energy intake was greater, in rats fed on the HFD (HFD provided $20.85 \mathrm{MJ} / \mathrm{kg}$ diet while $\mathrm{CD}$ provided only $16.65 \mathrm{MJ} / \mathrm{kg}$ diet). This effect is low and the Tukey's test was not able to show a statistical difference for these variables between the rats receiving 50 or $250 \mathrm{~g}$ of the same oil/kg (Table 4). Concerning body weight, ANOVA showed a difference between the rats fed on the CD and HFD. Body weight was less in rats fed on the HFD but this effect is low and the Tukey's test showed no statistical difference for this variable between the rats receiving 50 or $250 \mathrm{~g}$ of the same oil $/ \mathrm{kg}$ (Table 4). The liver weight was less in rats fed on the HFD. Previously, Ide et al. (1996) reported that a HFD did not affect the body weight of rats, but induced a slight but significant decrease of the liver weight.

\section{Maximum binding capacity and mRNA abundance of retinoic acid receptors}

$\mathrm{C}_{\max }$ and $K_{\mathrm{d}}$ were determined by Scatchard analysis (Fig. 2; Scatchard, 1949). The type or the level of dietary oil did not significantly affect $K_{\mathrm{d}}$ value. It was about $2 \mathrm{nM}$, a value in agreement with previous results obtained using CD367 as ligand (Sablonnière et al. 1994). In rats fed on the HFD (rich in SFA, in MUFA or in PUFA) the RAR $\mathrm{C}_{\max }$ was less than in rats receiving $50 \mathrm{~g}$ of the same oil $/ \mathrm{kg}$ (by $26 \%, 24 \%$ and $26 \%$ respectively) (Table 5). The abundance of RAR mRNA was also less in rats fed on the HFD than in rats fed on the CD (by $25 \%, 26 \%$ and $43 \%$ respectively).

\section{Retinoid $X$ receptor $\alpha$, peroxisome proliferator-activated receptor $\alpha$ and acyl-CoA oxidase $m R N A$ abundance}

The abundance of $\mathrm{RXR} \alpha$ mRNA was not significantly different in rats fed on the $250 \mathrm{~g} \mathrm{lipid} / \mathrm{kg}$ diets $v$. rats fed

Table 3. Effect of dietary oil type and level on variables in rats $†$ ( $F$ values (two-way ANOVA) for eight rats per group)

\begin{tabular}{|c|c|c|c|}
\hline & Oil type & Oil level & $T \times L \ddagger$ \\
\hline Food intake (g/d) & 0.20 & $9 \cdot 03^{*}$ & 0.69 \\
\hline Energy intake $(\mathrm{kJ} / \mathrm{d})$ & 0.21 & $9 \cdot 11^{*}$ & 0.65 \\
\hline Body weight (g) & 0.89 & $6 \cdot 63^{*}$ & $2 \cdot 70$ \\
\hline Liver weight $(\mathrm{g})$ & 0.23 & $25 \cdot 60^{*}$ & $2 \cdot 20$ \\
\hline $\mathrm{C}_{\max } \mathrm{RAR}$ (fmol/mg protein) & 2.02 & $63 \cdot 70^{*}$ & 0.02 \\
\hline RAR $\beta$ mRNA ( $\% \beta$-actin mRNA) & $1 \cdot 60$ & $57 \cdot 45^{\star}$ & 0.26 \\
\hline $\mathrm{RXR} \alpha$ mRNA ( $\% \beta$-actin mRNA) & 0.01 & 1.83 & 0.16 \\
\hline PPAR $\alpha$ mRNA ( $\% \beta$-actin mRNA) & 0.94 & $42 \cdot 46^{\star}$ & 0.17 \\
\hline Acyl-CoA oxidase mRNA ( $\% \beta$-actin mRNA) & 1.73 & $45 \cdot 40$ & 0.08 \\
\hline
\end{tabular}

$\mathrm{C}_{\max }$, maximum binding capacity; RAR, retinoic acid receptor; RXR, retinoid $\mathrm{X}$ receptor; PPAR, peroxisome proliferator-activated receptor.

${ }^{*} P<0.05$.

†For details of diets see Tables 1 and 2, and for procedures see pp. 666-667.

$\ddagger \mathrm{T} \times \mathrm{L}$, oil type and oil level interaction. 
Table 4. Effect of type and level of lipid in the diet on some biological variables in rats $\dagger$ (Mean values with standard errors for eight rats per group)

\begin{tabular}{|c|c|c|c|c|c|c|}
\hline \multirow[b]{2}{*}{ Variable } & \multicolumn{2}{|c|}{$\mathrm{CO}$} & \multicolumn{2}{|c|}{ ০০ } & \multicolumn{2}{|c|}{ so } \\
\hline & Mean & SE & Mean & SE & Mean & SE \\
\hline \multicolumn{7}{|l|}{ Food intake $(\mathrm{g} / \mathrm{d})$} \\
\hline $50 \mathrm{~g} \mathrm{lipid} / \mathrm{kg}$ & $19 \cdot 8$ & 0.6 & $20 \cdot 3$ & 0.6 & $19 \cdot 4$ & 0.5 \\
\hline $250 \mathrm{~g} \mathrm{lipid} / \mathrm{kg}$ & $17 \cdot 2$ & 1.0 & $17 \cdot 8$ & 0.8 & $18 \cdot 5$ & $1 \cdot 2$ \\
\hline \multicolumn{7}{|c|}{ Energy intake $(\mathrm{kJ} / \mathrm{d})$} \\
\hline $50 \mathrm{~g} \mathrm{lipid} / \mathrm{kg}$ & 331 & 11 & 337 & 10 & 332 & 8 \\
\hline $250 \mathrm{~g} \mathrm{lipid} / \mathrm{kg}$ & 358 & 22 & 370 & 16 & 384 & 26 \\
\hline \multicolumn{7}{|l|}{ Body weight (g) } \\
\hline $50 \mathrm{~g} \mathrm{lipid} / \mathrm{kg}$ & 316 & 6 & 301 & 7 & 317 & 12 \\
\hline $250 \mathrm{~g} \mathrm{lipid} / \mathrm{kg}$ & $281^{*}$ & 9 & 304 & 4 & 299 & 6 \\
\hline \multicolumn{7}{|l|}{ Liver weight (g) } \\
\hline $50 \mathrm{~g} \mathrm{lipid} / \mathrm{kg}$ & $15 \cdot 1$ & 0.5 & 14.5 & 0.5 & $15 \cdot 7$ & 0.9 \\
\hline $250 \mathrm{~g} \mathrm{lipid} / \mathrm{kg}$ & $12 \cdot 2^{*}$ & 0.7 & 13.5 & 0.7 & $12 \cdot 3^{*}$ & 0.5 \\
\hline
\end{tabular}

$\mathrm{CO}$, coconut-oil diet; OO, olive-oil diet; SO, safflower-oil diet.

Mean values were significantly different from those for rats receiving the diet containing $50 \mathrm{~g}$ of the same oil $/ \mathrm{kg}$ : ${ }^{*} P<0.05$ (Tukey's test).

†For details of diets see Tables 1 and 2, and for procedures see pp. 666-667.

on the $50 \mathrm{~g}$ lipid $/ \mathrm{kg}$ diets (Table 5). On the other hand, the $\operatorname{PPAR} \alpha$ mRNA abundance was greater (approximately $40 \%$ ) in the liver of rats fed on the HFD than in the liver of rats fed on the $\mathrm{CD}$ whatever the nature of the dietary lipid. Moreover, the level of acyl-CoA oxidase mRNA was also greater (approximately $40-50 \%$ ) in rats fed on the HFD whatever the nature of the dietary lipid. It is known that the activity of this enzyme is induced by drugs known to cause peroxisomal proliferation (Lazarow \& de Duve, 1976; Cherkaoui et al. 1991; Sterchele et al. 1996; Latruffe \& Vamecq, 1997). Moreover, an induction of PPAR $\alpha$ gene expression is related to a stimulation of acyl-CoA oxidase activity (Steineger et al. 1994). However, this is the first time that a possible link between the expression of PPAR and that of acyl-CoA oxidase has been shown in a nutritional experiment.

\section{Discussion}

The purpose of this present study was to demonstrate the effect of a HFD on the expression of RAR in rat liver and also to allow the analysis of the possible mechanisms involved by measuring the expression of related receptors. Animals receiving, for 4 weeks, diets enriched to a greater or lesser degree with lipids constituted the experimental model used. In the enriched diets, lipids represent $45.2 \%$ of the total energy provided by the diet. Thus, the lipidic status of the rats fed on the HFD could present some similitude with the status of human subjects whose diet is high in fat. Indeed, the contribution of fat to energy intake remains high in some western European populations (42\% of energy in people older than 40 years, according to a recent study performed in northern France (Lafay et al. 1998)).

We observed that an increased consumption of lipids was able to modify the expression of various nuclear receptors. The diets containing $250 \mathrm{~g}$ lipid/kg reduced the expression of nuclear RAR in rat liver. In a previous study we showed that a diet rich in SFA induces a decreased $\mathrm{C}_{\max }$ and a decreased amount of RAR mRNA (Bonilla et al. 1998). The (a)

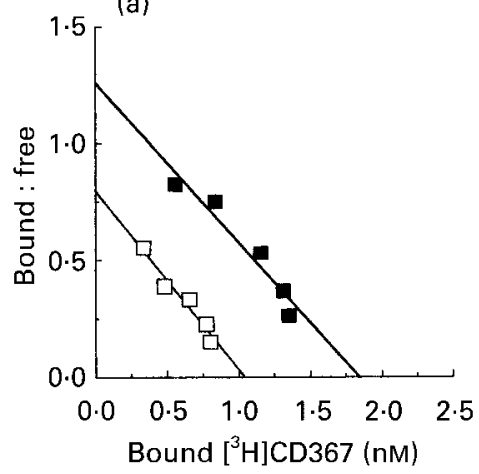

(b)

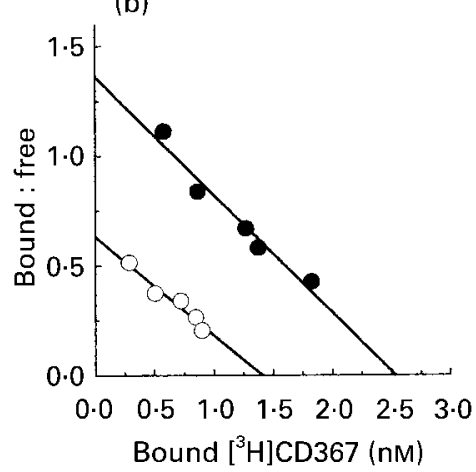

(c)

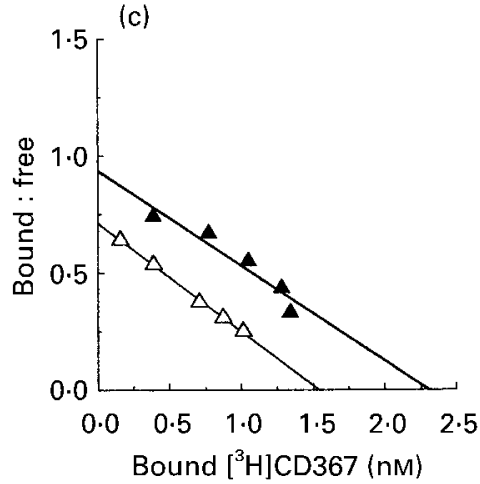

Fig. 2. Scatchard analysis (Scatchard, 1949) of $\left.{ }^{3} \mathrm{H}\right] \mathrm{CD} 367$ ligand specific binding to rat liver nuclear proteins. The curves are drawn by linear regression analysis; the slope gives the dissociation constant $\left(K_{d}\right)$ and the intercept of the slope with the abscissa represents the maximum binding capacity $\left(\mathrm{C}_{\max }\right)$. The plots represent six different determinations. Hepatic nuclear fractions were obtained from rats fed on (a) coconut-

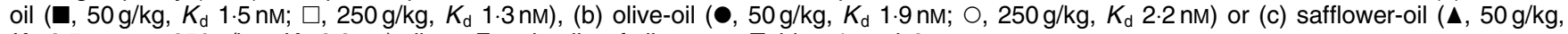
$\left.K_{\mathrm{d}} 2.5 \mathrm{~nm} ; \Delta, 250 \mathrm{~g} / \mathrm{kg}, K_{\mathrm{d}} 2.2 \mathrm{~nm}\right)$ diets. For details of diets see Tables 1 and 2. 
Table 5. Effect of type and level of dietary lipids on the retinoic acid receptor (RAR) expression and on the abundance of retinoid $\mathrm{X}$ receptors $(\mathrm{RXR}) \alpha$, peroxisome proliferator-activated receptors (PPAR) $\alpha$ and acyl-CoA oxidase mRNA in rat liver

(Mean values with standard errors)

\begin{tabular}{|c|c|c|c|c|c|c|c|c|c|c|}
\hline \multirow[b]{3}{*}{ Diet } & \multirow{2}{*}{\multicolumn{2}{|c|}{$\begin{array}{c}\mathrm{RAR} \mathrm{C}_{\max }{ }_{\text {(fmol/mg protein) }} \\
\text {. }\end{array}$}} & \multicolumn{8}{|c|}{ mRNA abundance $(\% \beta$-actin mRNA) $\ddagger$} \\
\hline & & & \multicolumn{2}{|c|}{$\operatorname{RAR} \beta$} & \multicolumn{2}{|c|}{$\mathrm{RXR} \alpha$} & \multicolumn{2}{|c|}{$\operatorname{PPAR} \alpha$} & \multicolumn{2}{|c|}{ Acyl-CoA oxidase } \\
\hline & Mean & SE & Mean & SE & Mean & SE & Mean & SE & Mean & SE \\
\hline \multicolumn{11}{|l|}{ Coconut oil } \\
\hline $50 \mathrm{~g}$ lipid/kg & 903 & 35 & $6 \cdot 0$ & 0.4 & $16 \cdot 0$ & $2 \cdot 2$ & $4 \cdot 1$ & 0.1 & $23 \cdot 8$ & $1 \cdot 3$ \\
\hline $250 \mathrm{~g} \mathrm{lipid} / \mathrm{kg}$ & $672^{*}$ & 25 & $4 \cdot 5^{\star}$ & 0.1 & $17 \cdot 8$ & 0.5 & $6 \cdot 0^{\star}$ & 0.5 & $36 \cdot 6^{*}$ & 1.9 \\
\hline \multicolumn{11}{|l|}{ Olive oil } \\
\hline $50 \mathrm{~g} \mathrm{lipid/kg}$ & 984 & 36 & $5 \cdot 7$ & 0.3 & $21 \cdot 8$ & 1.4 & 3.9 & 0.1 & $26 \cdot 0$ & 1.4 \\
\hline $250 \mathrm{~g} \mathrm{lipid} / \mathrm{kg}$ & $752^{*}$ & 20 & $4 \cdot 2^{*}$ & 0.1 & $17 \cdot 6$ & 1.7 & $5 \cdot 4^{*}$ & 0.1 & $37 \cdot 2^{*}$ & 3.8 \\
\hline \multicolumn{11}{|l|}{ Safflower oil } \\
\hline $50 \mathrm{~g}$ lipid/kg & 960 & 66 & 6.0 & 0.1 & $18 \cdot 8$ & $3 \cdot 1$ & 3.9 & 0.5 & 23.3 & $2 \cdot 0$ \\
\hline $250 \mathrm{~g}$ lipid/kg & $713^{*}$ & 33 & $3 \cdot 4^{*}$ & 0.1 & 21.4 & 0.3 & $5 \cdot 5^{\star}$ & 0.1 & $34 \cdot 3^{*}$ & 1.9 \\
\hline
\end{tabular}

$\mathrm{C}_{\max }$, maximum binding capacity.

Mean values were significantly different from those for rats receiving the diet containing $50 \mathrm{~g}$ of the same oil $/ \mathrm{kg}:{ }^{*} P<0.05$ (Tukey's test).

† Data from six rats per group.

$\ddagger$ Data from three different pools of two rats per group.

results of the present study show that a lipid-rich diet $(250 \mathrm{~g} / \mathrm{kg})$ induced a decrease in the expression of RAR in the liver of rats whatever the nature of the consumed lipid (either coconut oil which is rich in SFA, or olive oil which is rich in MUFA or safflower oil which is rich in PUFA).

This modulation of gene transcription could be the result of various mechanisms. One of them is that fatty acids may induce a modification of the cellular level of retinoic acid, which in turn induces a modification of RAR expression. Since retinol esterification can restrict retinol for retinoic acid production, factors that influence the deposition of endogenous retinyl esters in cells are regulators of the cellular concentration of the active retinoids. Thus, it was demonstrated in various cell types, including liver cells (Randolph \& Ross, 1991), that exogenous unesterified fatty acids increase the esterification of retinol. Moreover, in a study with cultured human epidermal keratinocytes, Randolph \& Simon (1995) showed that SFA as well as unsaturated fatty acids reduced the rate of retinyl ester utilization and the cellular concentration of retinol and retinoic acid. These authors claim that fatty acids have the potential to play a physiological role in modulating retinoid signalling by regulating the cellular concentration of active retinoids. Such a mechanism is interesting because in the rat liver the subtype $\operatorname{RAR} \beta$ is upregulated by retinoic acid (Kato et al. 1992) and thus a lower cellular content of retinoic acid could be related to underexpression of RAR.

The results obtained in this study, however, constitute arguments in favour of an alternative hypothesis. Indeed, fatty acids may interact with cell signalling pathways by modifying the balance between nuclear receptors. Recent studies suggest that fatty acids can modulate the transcription of genes involved in their own metabolism (Shoonjans et al. 1996) and some of these effects are mediated by activation of PPAR. The positive regulation of gene expression by PPAR has been shown to involve the binding of PPAR to specific response elements through heterodimerization with the 9-cis retinoic acid receptor $\mathrm{RXR} \alpha$. This indicates that the retinoid and peroxisome proliferator signalling pathways converge through the direct interaction of their respective nuclear hormone receptors (Gearing et al. 1993; Miyata et al. 1994). Moreover, it was shown that RXR form heterodimers in solution with RAR and the determination of its efficiency and selectivity suggest that these heterodimers are the functional units that transduce the hormonal signal in vivo (for review see Chambon, 1996). In this latter experiment, an activation of PPAR by fatty acids could indirectly modify RAR expression by competing with RAR for the common auxiliary coregulator RXR. These findings could explain our results since we observed that the decreased expression of RAR occurred simultaneously with an increased expression of PPAR. The abundance of RXR mRNA was not affected by the diets, probably because the hepatic pool of RXR is large and not easily changeable (DiRenzo et al. 1997).

In summary, evidence is provided here that HFD, whatever the nature of the fatty acids most abundant in the diet (SFA or MUFA or PUFA), are able to modify the expression of certain receptors and among them RAR which are involved in growth, differentiation and cellular homeostasis. The mechanisms responsible for the decrease of RAR are probably multiple but it can be considered that an important role is played by the modification of the equilibrium between nuclear receptors induced by the increased expression of PPAR. Indeed, the formation of heterodimers PPAR/ RXR could decrease the availability of RXR to constitute RAR/RXR which positively modulate the transcription of RAR genes. Such a decreased expression of RAR can be related to the fact that peroxisome proliferators induce tumour formation in rodent liver (for review see Cattley et al. 1998). Moreover, since RAR $\beta$ has differentiation and antiproliferation effects ( $\mathrm{Li} \&$ Wan, 1998) the decreased expression of this receptor can be related to the occurrence of certain types of cancers observed after long-term consumption of a HFD. 


\section{Acknowledgement}

Supported in part by the Conseil Régional d'Aquitaine (Fonds Commun de Coopération: Aquitaine (France)Navarra (Spain)-Euskadi (Spain)).

\section{References}

Audouin-Chevallier I, Higueret P, Pallet V, Higueret D \& Garcin H (1993) Dietary vitamin A modulates the properties of retinoic acid and glucocorticoid receptors in rat liver. Journal of Nutrition 123, 1195-1202.

Bonilla S, Noël-Suberville C, Puy-Portillo M, Edurne S, Del Barrio A, Garcin H \& Higueret P (1998) A diet rich in coconut oil decreases the expression of retinoic acid and triiodothyronine nuclear receptors in rat liver. Nutrition Research 18, 15951604.

Braissant O, Foufelle F, Scotto C, Dauca M \& Wahli W (1996) Differential expression of peroxisome proliferator-activated receptor (PPARs): tissue distribution of PPAR- $\alpha,-\beta$ and $-\gamma$ in the adult rat. Endocrinology 137, 354-366.

Cattley RC, DeLuca J, Elcombe C, Fenner-Crisp P, Lake BG, Marsman DS, Pastoor TA, Popp JA, Robinson DE, Schwetz B, Tugwood J \& Wahli W (1998) Do peroxisome proliferating compounds pose a hepatocarcinogenic hazard to humans? Regulatory Toxicology and Pharmacology 27, 47-60.

Chambon P (1996) A decade of molecular biology of retinoic acid receptors. FASEB Journal 10, 940-954.

Cherkaoui M, Assaka L, Pacot C, Bardot O \& Latruffe N (1996) Effect of different hypolipemic agents on rat liver peroxisomal and mitochondrial functions and biogenesis. Cellular and Molecular Biology 37, 723-733.

Clarke SD \& Jump DB (1993) Fatty acid regulation of gene expression: a unique role for polyunsaturated fats, pp. 227246. In Nutrition and Gene Expression [C Bernadier and JL Hargrove, editors]. Boca Raton, FL: CRC Press.

Coustaut M, Pallet V, Garcin H \& Higueret P (1996) The influence of dietary vitamin A on triiodothyronine, retinoic acid and glucocorticoid receptors in liver of hypothyroid rats. British Journal of Nutrition 76, 295-306.

DeGroot LJ \& Torresani J (1975) Tri-iodothyronine binding to isolated liver cell nuclei. Endocrinology 96, 357-369.

DiRenzo J, Söderström M, Kurokawa R, Ogliastro MH, Ricote M, Ingrey S, Hörlein A, Rosenfeld MG \& Glass CK (1997) Peroxisome proliferator-activated receptors and retinoic acid receptors differentially control the interactions of retinoic $X$ receptor heterodimers with ligands, coactivators and corepressors. Molecular and Cellular Biology 17, 2166-2176.

Folch J, Lees M \& Stanley GHS (1957) A simple method for the isolation and purification of total lipides from animals tissues. Journal of Biological Chemistry 226, 497-509.

Gearing KL, Göttlicher M, Teboul M, Widmark E \& Gustafsson J-Å (1993) Interaction of the peroxisome proliferator-activated receptor and retinoid X receptor. Proceedings of the National Academy of Sciences USA 90, 1440-1444.

Green S \& Whali W (1994) Peroxisome proliferator-activated receptors: finding the orphan a home. Molecular and Cellular Endocrinology 100, 149-153.

Haq RU, Pfahl M \& Chytil F (1991) Retinoic acid affects the expression of nuclear retinoic acid receptors in tissues of retinoldeficient rats. Proceedings of the National Academy of Sciences USA 88, 8272-8276.

Ide T, Murata T \& Sugano M (1996) Stimulation of the activities of hepatic fatty acid oxidation enzymes by dietary fat rich in $\alpha$-linolenic acid in rats. Journal of Lipid Research 37, 448463.
Isseman I \& Green S (1990) Activation of a member of the steroid hormone receptor superfamily by peroxisome proliferators. Nature 347, 645-650.

Kato S, Mano H, Kumazawa T, Yoshizawa Y, Kojima R \& Masushige S (1992) Effect of retinoid status on $\alpha, \beta$ and $\gamma$ retinoic acid receptor mRNA levels in various rat tissues. Biochemical Journal 286, 755-760.

Keller H, Dreyer C, Medin J, Mahfoudi A, Ozato K \& Wahli W (1993) Fatty acids and retinoids control lipid metabolism through activation of peroxisome proliferator-activated receptor-retinoid $\mathrm{X}$ receptor heterodimers. Proceedings of the National Academy of Sciences USA 90, 2160-2164.

Kliewer SA, Sundseth SS, Stacey AJ, Brown PJ, Wisely GB, Koble CS, Devchand P, Wahli W, Willson TM, Lenhard JM \& Lehmann JM (1997) Fatty acids and eicosanoids regulate gene expression through direct interactions with peroxisome proliferator-activated receptors $\alpha$ and $\gamma$. Proceedings of the National Academy of Sciences USA 94, 4318-4323.

Lafay L, Vray M, Boute D \& Basdevant A (1998) Food and nutritional data for a population from northern France: the Fleurbaix Laventie Ville Sante (FLVS) Study. Revue d'Epidemiologie et Santé Publique 46, 263-275.

Latruffe N \& Vamecq J (1997) Peroxisome proliferators and peroxisome proliferator activated receptors (PPARs) as regulators of lipid metabolism. Biochimie 79, 81-94.

Lazarow PB \& De Duve C (1976) A fatty acyl-CoA oxidizing system in rat liver peroxisomes, enhancement by clofibrate, a hypolipidemic drug. Proceedings of the National Academy of Sciences USA 73, 2043-2046.

Li C \& Wan YJ (1998) Differentiation and antiproliferation effects of retinoic acid receptor beta in hepatoma cells. Cancer Letters 124, 205-211.

Mangelsdorf DJ, Borgmeyer U, Heyman RA, Zhou JY, Ong ES, Oro AE, Kakizuka A \& Evans RM (1992) Characterization of three RXR genes that mediate the action of 9-cis retinoic acid. Genes and Development 6, 329-344.

Mangelsdorf DJ, Umesono K \& Evans RM (1994) The retinoid receptors. In The Retinoids: Biology, Chemistry, and Medicine, pp. 319-349 [MB Sporn, AB Roberts and DS Goodman, editors]. New York, NY: Raven Press.

Miyata KJ, McCaw SE, Marcus SL, Rachubinski RA \& Capone JP (1994) The peroxisome proliferator-activated receptor interacts with the retinoid X receptor in vivo. Gene 148, 327-330.

Noël-Suberville C, Pallet V, Audouin-Chevallier I, Higueret P, Bonilla S, Martinez AJ, Zulet MA, Portillo MP \& Garcin H (1998) Expression of retinoic acid, triiodothyronine, and glucocorticoid hormone nuclear receptors is decreased in the liver of rats fed a hypercholesterolemia-inducing diet. Metabolism 47, 301-308.

Pallet V, Audouin-Chevallier I, Higueret D, Garcin H \& Higueret P (1996) Dexamethasone decreases the expression of retinoic acid receptors (RARs) in rat liver. Journal of Steroid Biochemistry and Molecular Biology 57, 161-165.

Pallet V, Audouin-Chevallier I, Verret C, Garcin H \& Higueret P (1994) Retinoic acid differentially modulates triiodothyronine and retinoic acid receptors in rat liver according to thyroid status. European Journal of Endocrinology 131, 377-384.

Poirier H, Braissant O, Niot I, Wahli W \& Besnard P (1997) 9-cis retinoic acid enhances fatty acid-induced expression of the liver fatty acid-binding protein gene. FEBS Letters 412, 480-484.

Pottier de Courcy G, Durand G, Abraham J \& Gueguen L (1989) Recommendations sur les conditions d'alimentation des animaux de laboratoire (rats et souris) (Dietary recommendations for laboratory animals (rats and mice)). Sciences des Aliments $\mathbf{9}$, 209-217.

Randolph RK \& Ross C (1991) Regulation of retinol uptake and 
esterification in MCF-7 and HepG2 cells by exogenous fatty acids. Journal of Lipid Research 32, 809-820.

Randolph RK \& Simon M (1995) Metabolic regulation of active retinoid concentrations in cultured epidermal keratinocytes by exogenous fatty acids. Archives of Biochemistry and Biophysics 318, 6-14.

Sablonnière B, Dallery N, Grillier P, Formstecher P \& Dautrevaux M (1994) Physicochemical parameters affecting the charcoal adsorption assay for quantitative retinoid-binding measurement. Analytical Biochemistry 217, 110-118.

Scatchard D (1949) The attractions of proteins for small molecules and ions. Annals of the New York Academy of Sciences 51, 660672.

Shoonjans K, Staels B \& Auwerx J (1996) Role of the peroxisome proliferator-activated receptor (PPAR) in mediating the effects of fibrates and fatty acids on gene expression. Journal of Lipid Research 37, 907-925.

Steineger HH, Sorensen HN, Tugwood JD, Skrede S, Spydevold O
\& Gautvij KM (1994) Dexamethasone and insulin demonstrate marked and opposite regulation of the steady-state level of the peroxisomal proliferator-activated receptor (PPAR) in hepatic cells: hormonal modulation of fatty-acid-induced transcription. European Journal of Biochemistry 225, 967-974.

Sterchele PF, Sun H, Peterson RE \& Vanden Heuvel JP (1996) Regulation of peroxisome proliferator-activated receptor-alpha mRNA in rat liver. Archives of Biochemistry and Biophysics 326, 281-289.

Verma AK, Shoemaker A, Simsiman R, Denning M \& Zachman R (1992) Expression of retinoic acid nuclear receptors and tissue transglutaminase is altered in various tissues of rat fed with a vitamin A-deficient diet. Journal of Nutrition 122, 2144-2152.

Villaroya F (1998) Differential effects of retinoic acid on white and brown adipose tissues. An unexpected role for vitamin A derivatives on energy balance. Annals of the New York Academy of Sciences 839, 190-195. 